\title{
AN ANALYSIS OF THE CHARACTER OF MANAGEMENT OF CONTROL AND MEASURING EQUIPMENT IN SMALL AND MEDIUM ENTERPRISES
}

\begin{abstract}
The paper describes selected problems concerning the character of management of control and measuring equipment in small and medium enterprises. There are discussed the oversight process over control and measuring equipment as well as there are itemized duties of people managing manufacturing process and worker who controls measuring equipment. There are briefly discussed selected problems concerning the calibration of control and measuring equipment as well as preparing of a workplace for its control. Conclusions are drawn concerning particular activities significantly influencing the management of control and measuring equipment.
\end{abstract}

Keywords: measuring equipment, MSA, management, small and medium enterprises.

\section{INTRODUCTION}

Polish sector of enterprises is dominated by small and medium enterprises (SME), which constitute approximately $99,8 \%$ of all enterprises playing active role in economy. According to the PART report of 2017, made on the grounds of data collected by Statistics Poland (SP), $96 \%$ of the whole sector constituted by microenterprises and $3 \%$ small enterprises. Medium enterprises form only 0,8\% (Nieć, Łapiński, Orłowska, Zakrzewski, Chaber, Widła-Domaradzki, Domaradzka, 2017). About 92,8\% of SME are private ones (Czerniak, Stefański, b.d.). They manufacture a constantly growing part of Polish Gross Domestic Product (GDP). They have to face strong competition, acting simultaneously with other companies from the sector, selling or manufacturing products applied for the same or similar purposes.

One of the important factors influencing competitiveness and the ability to maintain clients is the quality of products. Therefore, a management system based on the grounds of the ISO 9001 standard is used. It determines typical actions in all areas of activities in an enterprise, including maintaining product quality. The ISO 9001:2015 standard, known in Poland as a PN-EN ISO 9001:2015-10 (“PCBiC", b.d.), is strongly linked with complementary standards such as IATF 16949 (IATF 16949:2016, 2016) which concern systems for the management of measurements and requirements related to measuring processes and measuring equipment. They are addressed in section 7.1.5 of the standard with the name "Principles of monitoring and measuring". That section is a part of chapter 7 entitled "Support". Even though the implementation of the ISO 9001 system brings benefits for enterprises in the form of growing number of clients and improvement of the organization of work, some

\footnotetext{
${ }^{1}$ Małgorzata Kawalec MSc, Rzeszów; e-mail: mkawalec@onet.eu. ORCID: 0000-0003-3612-0971.
} 
of them decide not to carry on costs of implementation and move through long lasting process of certification of the quality management system (QMS). It usually takes place in case of small companies with small material and financial resources. In such companies production lines should be controlled, in order to maintain the quality of products, by using various control and measuring tools applied to monitoring of manufactured products' parameters. Systematic oversight of the manufacturing process enables reacting to abnormalities and preventing form their occurrence in the future. It limits customers' complaints, company's losses and losing customers. The selection of applied measuring equipment should follow manufacturing processes and tasks as well as standards the products must fulfill. The properties of measuring equipment, such as accuracy class, sensitivity, factors influencing the uncertainty of measuring and other must be compatible with the products' demands.

The oversight of the proper work of measuring equipment, considering its wear and dysregulation, becomes a very important building block of a capable system for maintaining quality of manufacturing. It influences the results of measuring and selecting defective products. Therefore, it is important to early detect and diagnose diminishing measuring equipment capability by regular analyses of its stability of work. The requirement of preserving suitable quality of measuring equipment become the main reason for developing of systems focused on monitoring the state of measuring equipment named Measurement System Analysis (MSA) (Sałaciński, 2009). Those systems assert that the measuring equipment and processes are adjusted to their areas of application which influences the management of risk associated with improper measuring results (Sałaciński, 2015). Full scale MSA can be applied by enterprises which have suitable isolated branches with qualified staff operating even complex measuring systems (Król, Ludwiczyński, 2006). Smaller manufacturers not always have, however, enough financial resources to operate extended systems. On the other hand, they must properly control manufacturing process and check the way of using their measuring equipment. The solution may be the implementation of simplified MSA and executing it by some member of staff designated to those tasks within a part of his or her working time.

\section{THE MANAGEMENT OF CONTROL AND MEASURING EQUIPMENT}

Decision concerning the implementation of control and measuring equipment management usually belongs to the company's owner. Small and medium enterprises being primarily private ones are managed by a single manager who decides about strategic and current operational processes (Tomasik [red.], Arendarski, Gliwa-Gliwiński, Jabłoński, Ratajczyk, Żebrowska-Łucyk, 2009). In the case of big enterprises the system for supervising of measuring equipment can run separately for each production division and be supervised by several members of staff. In small companies, however, such task may be usually maintained by a single person within a part of his/her working time. The rule is - smaller the number of measuring instruments of one type, more cost effective becomes outsourcing the task to external laboratories (Tomasik [red.] i in., 2009). Companies having enough financial resources frequently apply various ready to use systems for supervising measuring equipment. Some of the systems enable customization to individual needs of particular company and some not. Enterprises selecting suitable system take into consideration its compliance with current standards, flexibility of software, compatibility with possessed equipment, range of capabilities and universality. In small enterprises which are unable to implement extended control systems but plan to carry out the control of possessed mea- 
suring equipment by implementing even simplified MSA the solution lies in preparing a control workstation and training a member of staff designated to supervise control and measuring equipment.

\subsection{Supervision process over the control and measuring equipment}

Properly realized supervision process begins with acquisition of control and measuring equipment and ends with withdrawing it from operation. Regular supervision over the state of measuring instruments increases the probability of their proper work. It also gives better assurance for the compliance of products with requirements and decreases potential losses following bad quality of products. Duties associated with supervising of control and measuring equipment depends on the size of company, the amount and type of measuring equipment, assortment of products, type of manufacturing (small, medium or large size production), organization and type of control (incidental or full and systematic control).

Developing of an efficient management system for control and measuring equipment requires determining of tasks realized at workplaces designated for supervising control and measuring system. For that purpose there are required the following:

- specification of all measurements made and applied instruments used in a company;

- identification and making an detailed inventory of the whole measuring equipment;

- developing procedures for labeling of applied equipment;

- determining calibration periods;

- preparing management system documentation - procedures, instructions, forms, model documents suitable for all applied tools

- determining periodical checks of applied measuring equipment;

- estimating the time necessary for worker to control the equipment (Baderska, Zakrzewska-Bielawska, 2007).

Company's success depends on people, their knowledge, skills, experience and involvement into work. It is especially important in small enterprises where new workers are employed with special attention paid to recommendation and familial connections (Król, Ludwiczyński, 2007). Poor workforce with low level of professional competencies makes impossible for any company to stay competitive in only short period of time (Tomasik [red.] $\mathrm{i}$ in., 2009). In long term it may lead to company's fall. If company's owner thinks about the strategy of development and plans to implement in the company the process of checking measuring instruments, he/she should reasonably choose a worker for that task, because the staff plays the key role in the QMS. It is important that the person designated to checking measuring instruments:

- has suitable professional experience,

- has at least basic knowledge in metrology,

- can properly apply measuring instruments,

- is willing to upgrade professional qualifications e.g., through technical trainings.

The following psychophysical features are also important: accuracy, perceptivity, systematicity, scrupulousness, patience, discipline, good contact with people and good eyesight necessary for initial check of the state of investigated tools.

The organization of measuring equipment management requires:

- determining of worker's hours, within work time, devoted to tasks associated with checking of measuring instruments; 
- designation of duties to particular worker;

- determining the method of gratification for making additional work;

- preparing a workplace checking measuring instruments.

Initially prepared range of process of control and measuring equipment management in considered company may change and evolve in result of the company's development and improvement of workers' professional qualifications.

\subsection{Duties of worker supervising of control and measuring equipment}

Determining of duties for the worker who ought to supervise control and measuring equipment should be done in result of common arrangements between the employer and that worker. The worker who gained eg., through trainings, technical knowledge and raised qualifications can be very helpful source of knowledge for the employer in the process of building of an efficient system of supervising. Among tasks associated with supervising control and measuring equipment should be:

- Making the inventory of measuring equipment by suitable taking new measuring instruments into its warehouse: setting of a record card with its identification number (it should be glued to considered measuring instrument), product number, the name of a person responsible for particular tool. That record card should be made in an electronic form within a database software e.g., a spreadsheet. It should be also printed on paper and put into a binder with other documents linked with measuring instrument, such as operation manual, certificate of calibration, warranty card, etc.

- Withdrawal of warn tools from company's warehouse.

- Developing of a book with information about the quality of all tools and time-schedule of their use.

- Cooperating with accredited measurement laboratories.

- Creating of reports and measurement protocols.

- Creating of time-schedule of calibration and supervising calibration processes.

- Creating of circulation cards for all considered equipment.

- Watching and checking whether the person responsible for particular equipment or instrument - usually master or foreman - fulfills the requirement concerning submitting the instrument to control branch before instrument's validity date.

- In the case of simple measuring tools, like calipers, micrometer, depth gauges, etc., checking their capability by conducting at least simplified MSA allowing to approximately estimate the necessity of soon calibration of the measuring instruments.

- Conducting of the registry of calibration and controlling the evidence of measuring instruments calibrations.

The above named tasks should be done in a systematic way and according to some predefined time-schedule. Only regular procedure of collecting and analyzing of measurements enables to estimate and establish allowable levels of important control parameters concerning control and measuring equipment. It also enables determining the successive periods of calibration of used instruments or withdrawal of worn ones.

\subsection{Calibration of control and measuring instruments}

One of the most important tasks in the field of monitoring of control and measuring equipment is watching over its systematic calibration, i.e. establishing relation between 
metrological values of measured feature shown by each considered measuring instrument and metrological values determined with the use of measurement unit patterns (Lewicka, 2017). Some enterprises try to make calibration themselves, especially when it concerns simple measuring instruments. Other enterprises outsource calibration to accredited companies to omit checking failures and to obtain calibration certificate. Such certificate is a document issued e.g., by Central Office of Measures (COM), district offices of measures, measurement laboratories. Those organizations and companies state in such certificate that the calibrated measuring instrument fulfills certain metrological requirements.

Freestanding calibrations can be done by organizations having qualified staff, suitable conditions for making such measurements and necessary reference patterns. Calibrating of measuring instruments should be repeated for each instrument in certain periods of time as long as that instrument is applied for metrological purposes. Currently there are no mandatory rules of law determining calibration periods. Neither expiry dates are indicated on calibration certificates. The exception are measuring instruments under mandatory legal metrological control i.e., instruments applied in the areas such as: health care, protecting live and environment, security and public order, consumer rights, collection of fees and taxes as well as other budgetary bills, determining discounts, etc.

In the case of other areas of using measuring instruments dates of calibration are established by their owner. In the case of small and medium enterprises it can be done by a trained member of staff designated for such tasks. The frequency of calibration varies for different measuring instruments and for each calibrated instrument depends on:

- the type of its design;

- conditions concerning the environment if its operation (temperature, humidity, pollutants, vibrations, presence of caustic materials etc.);

- competences and experience of staff operating considered instrument;

- frequency of its operation;

- diligence associated with its maintenance and storage, etc.

Calibrations should be done in such periods that successive checking and calibration is performed before probable change of accuracy of measuring instrument. There should be kept some balance concerning the frequency of calibration, because too often calibrations are also to expensive as they require removing of a measuring instrument to be calibrated from the process of regular measurements of products and replacing it with other valid measuring instrument. Therefore, it becomes very important to determine the terms of calibration on the grounds of proper estimation of instrument's wear or its dysregulation. It influences economic benefits, because the continuous assertion of required accuracy of measuring instruments diminishes the number of defective products and limits the number of complaints. Those actions are crucial for the effective work of a quality control system.

\subsection{Preparing of a workplace for supervising of control and measuring equipment - metrological chamber}

Permanent performance of duties associated with supervising of control and measuring equipment requires taking care of infrastructure and environment for supervising. It connects with selecting of a separate room which should be an independent workplace for the inspection of measuring instruments - metrological chamber. That room is not required to fulfill requirements associated with measurement laboratories. However, it is desirable that the metrological chamber is well separated from the rest of a production hall and meets 
several conditions. One of them is limited access of a daylight which should not fall on measurement patterns, measuring instruments and parts prepared for measuring. Inside that chamber there should be a couple of sources of artificial light, not too much intensive, preferably incandescent light (tungsten) (Tomasik [red.] i in., 2009): a roof lamp, a lamp on a desk near a computer used in the process of measuring and a good lamp on a measuring table. The temperature should be stable and moderate, approximately $20^{\circ} \mathrm{C}$. There should be also supplied:

- lockable file cabinets for binders with documentation dedicated to all measuring instruments used in a company, cabinets for storage of calibration patterns and instruments which are assumed to be forwarded for calibration in an external laboratory;

- measuring table on which it is possible to properly put instruments for checking their general state;

- computer with suitable software.

Such workplace, separated from the rest of a production hall, makes possible focusing on tasks requiring precise checking and measurements of measuring instruments and performing their calibration. It can also be used for storage of documents associated with control and measuring equipment owned by the company as well as the place for temporary storage of tools being checked in the context of their dimensional accuracy, crucial geometric parameters and stability of using them in manufacturing process.

\section{CONCLUSIONS}

Performed analysis of the character of control and measuring equipment management in small and medium enterprises leads to the following conclusions:

1) The application of quality control in a company significantly influences company's economy. There exist, however, not too much publications showing economic benefits following the application of metrology in manufacturing of various products. Several analyses showed that properly chosen measurement processes performed with capable measuring instruments brings a new added value to each manufactured product. The use of respectively selected and supervised measuring systems allows to eliminate defective products and limit costs of losses (Savio, De Chiffre, Carmignato, Meinertz, 2016).

2) High quality of manufactured products is one of the most important factors deciding about the market success and competitive advantage in dynamically changing economy. Capable control and measuring equipment and qualified staff trained to use that equipment are obligatory basis for maintaining quality independently from the size of enterprise. Monitoring of measuring instruments is one of the necessary elements of integrated system for management of quality, environment and energy, according to the ISO 9001, ISO 14001 and ISO 30001 standards.

3) Not all enterprises are able co carry costs of expensive systems. However for each of them the quality of manufactured products is a priority. Therefore, it is very worth to establish and make well working at least a simplified system for control of measuring equipment quality. If a company is not able to employ a new worker with suitable knowledge and skills in metrology, it should take care of improving metrological qualifications of some member of staff designated for that purposes.

4) The staff supervising control and measuring equipment plays a key role in quality management of the equipment. Managing staff should take care of thorough training 
of staff, taking the opportunity of wide offer of technical trainings devoted to both metrological problems and the methodology of supervising various processes.

5) It is also important that the tasks associated with supervising of measuring equipment and realized in only some part of working time of designated worker are not at the bottom of the list of his/her activities. The worker must be conscious of the importance concerning quality control of both products and measuring equipment. Suitable material and nonmaterial motivating as well as proper rewarding of that worker are also central factors influencing the effectiveness of the quality control system and bring benefits for the company. The managing staff should take care on preparing suitable infrastructure and environment for such worker.

6) The effectiveness of quality control of both products and measuring equipment can be significantly improved by using proper mathematical methods of analysis and their practical application in the form of suitable software dedicated for that purpose. Such software facilitates the execution of work associated with collecting and processing data obtained in the process of quality control. It also accelerates access to information concerning used measuring instruments, the evidence of control and supervising processes, calibrating of measuring instruments and their attestation. It simplifies determination of instruments' checking periods. Some software packages are small and narrow as far as their application is concerned (Magdziak, 2014). There are also general and relatively expensive software packages enabling to design and run measurements and test stands. Small packages are usually developed by companies manufacturing measuring equipment. However, it can be a difficult task to correctly transfer data from a specialized software focused on particular measuring instrument to main management system e.g., software which may used for the MSA.

Implementation of the above named procedures associates with additional work and costs for the company. However, in the final result it becomes profitable for the company as it both improves the level of control of manufacturing process and strengthens position of the enterprise on highly competitive market.

\section{REFERENCES}

Tomasik, J., Arendarski, J., Gliwa-Gliwiński, J., Jabłoński, Z., Ratajczyk, E., Żebrowska-Łucyk, Z. (2009). Sprawdzanie przyrzadów do pomiaru dtugości i kąta. Warszawa: Oficyna Wydawnicza Politechniki Warszawskiej.

Baderska, S., Zakrzewska-Bielawska, A. (2007). Cechy pracy kierowniczej w matych i średnich przedsiębiorstwach (na przykładzie firm regionu łódzkiego) [w:] Matejun, M., Lachiewicz, S., red. Problemy wspótczesnej praktyki zarzadzania. Łódź: Wydawnictwo Politechniki Łódzkiej.

Magdziak, R. (2014). Systemy pomiarowe staja się podstawowym narzędziem zapewniajacym wysoka jakość $i$ oszczędność $w$ przemyśle [Access: 11.06.2018]. Access on the internet: https://elektronikab2b.pl/raporty/24725-systemy-pomiarowe-staja-sie-podstawowym-narzedziem-zapewniajacym-wysoka-jakosc-i-oszczednosc-w-przemysle

Lewicka, A. (2017). Prawna kontrola metrologiczna [Access: 11.06.2018]. Access on the internet: http://gum.gov.pl/pl/uslugi/certyfikacja/1314,Prawna-kontrola-metrologiczna.html? search=97469735098807

Król, H., Ludwiczyński, A., (2007). Zarzadzanie kapitałem ludzkim a konkurencyjność małych i średnich przedsiębiorstw, „Zarządzanie Zasobami Ludzkimi” 3-4/2007. 
Król, H., Ludwiczyński, A. (2006). Zarządzanie Zasobami Ludzkimi, Warszawa: Wydawnictwo Naukowe PWN.

Nieć, M., Łapiński, J., Orłowska, J., Zakrzewski, R., Chaber, P., Widła-Domaradzki, Ł., Domaradzka, A. (2017). Raport o stanie sektora MSP w Polsce 2018 [Access: 15.06.2018]. Access on the internet: https://www.parp.gov.pl/component/publications/publication/raport-o-staniesektora-msp-w-polsce-2017

[PCBiC]. (b.d.) [Access: 15.06.2018]. Access on the internet: https://www.pcbc.gov.pl/pl/ uslugi/certyfikacja-systemow-zarzadzania/pn-en-iso-9001

Sałaciński, T. (2015). Nadzorowanie procesów obróbki skrawaniem z wykorzystaniem metrologii oraz systemów PCP i MSA. „Mechanik” Nr 08/09/2015.

Sałaciński, T. (2009). SPC statystyczne sterowanie procesami produkcji. Warszawa: Oficyna Wydawnicza Politechniki Warszawskiej.

Savio, E., De Chiffre, L., Carmignato, E., Meinertz, J, (2016). Economic benefits of metrology in manufacturing. CIRP Annals. Vol. 65. Issue 1.

Czerniak, A., Stefański, M., (b.d.) Mate i średnie firmy w Polsce - bariery $i$ rozwój [Access: 14.06.2018]. Access on the internet: https://www.politykainsight.pl/_resource/multimedium/ 20091348

Standard systemu zarzązania jakością w przemyśle motoryzacyjnym. IATF 16949:2016. Wymagania względem systemów zarządzania jakościa dla produkcji seryjnej oraz produkcji części serwisowych w przemyśle motoryzacyjnym. (2016). Pszczyna: Wydawnictwo Team Prevent.

DOI: $10.7862 /$ rz.2019.hss.5

The text was submitted to the editorial office: July 2018.

The text was accepted for publication: March 2019. 